\title{
SPOŁECZEŃSTWO
}

\section{Katarzyna Pawlak}

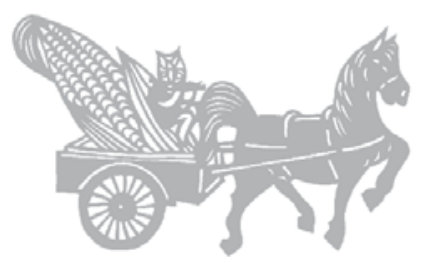

\section{SYSTEM WARTOŚCI NA TAJWANIE. JAKA „TRADYCJA"? JAKA „NOWOCZESNOŚĆ"?}

\section{Jaka perspektywa?}

Coraz bardziej widoczny spektakularny sukces ekonomiczny wielu krajów Azji Wschodniej w latach 80. ubiegłego wieku spowodował odrodzenie się dyskursu o relacji pomiędzy sukcesem gospodarczym a wymiarem kulturowym danego społeczeństwa, tym razem w odniesieniu do Azji Wschodniej. Dyskurs ten, początkowo prowadzony w kręgach zachodnich nauk społecznych i politycznych ${ }^{1}$, poświęcał wiele uwagi azjatyckim systemom kulturowym, a zwłaszcza konfucjanizmowi, jako czynnikowi „,sprawczemu” w stosunku do notowanych sukcesów. Przeniesienie idei przyczynowego wynikania sukcesów z konfucjańskiej tradycji na grunt dyskursu Azji Wschodniej było jednocześnie przeniesieniem dyskusji w sferę polityki. Rządy niektórych krajów wschodnioazjatyckich wobec niewątpliwego sukcesu ekonomicznego gospodarek państwowych próbowały na nowo zredefiniować charakter legitymacji własnej władzy - nie tylko wobec wzorów demokratycznych, które legalność władzy upatrywały w procedurach wyborczych, ale także wobec oczekiwań i wyobrażeń obywateli własnych krajów, jak również wobec rodzimych tradycji rządzenia i układów władzy. Te poszukiwania współczesnego typu legitymacji owocowały nowymi koncepcjami politycznymi, które miały łączyć w sobie sposoby legitymizacji niesione przez tradycję (jej rekonstruowaniu czy wręcz konstruowaniu poświęcano równie wiele uwagi) oraz formy niesione przez zmienia-

${ }^{1}$ D. A. Bell, Chaibong Hahm, Confucianism for the modern world, Cambridge 2003. 
jącą się rzeczywistość. Jak zauważa, nie bez ironii, Chua Beng-Huat, układ taki często w rzeczywistości wielu pół-autorytarnych krajów Azji Wschodniej połowy lat 80. oznaczał ,polepszenie standardu życia w zamian za ograniczenia wolności politycznej”'2. Wschodnioazjatyckie nauki społeczne również podjęły w końcu wyzwanie scalenia tradycyjnych koncepcji rządzenia i nowoczesności, czego nieodłącznym elementem, była - jak zaznacza M. L. Barr - próba dekonstrukcji zachodnich pojęć opisujących rzeczywistość społeczną. Na tej zasadzie np. podjęto się dekonstrukcji „liberalnej demokracji na jej części składowe - liberalizm i demokrację"3. Wśród owoców tych działań jako interesującą formalnie można wymienić chociażby koncepcję demokracji konfucjańskiej - akcentującej moralną ważność relacji jednostki z władzą. Ważność ta wypływać miała $\mathrm{z}$ definicji jednostki - gdyż ,ja" miało osiągać swój właściwy wymiar, także moralny, jedynie poprzez zapośredniczenie w szerszych strukturach - rodzinnych, wspólnotowych oraz strukturze władzy państwowej. Władza nie stanowiła opresyjnej opozycji dla rządzonych - wręcz przeciwnie - to jej działania pozwalały każdej jednostce na prawidłowy rozwój społeczny.

Sama koncepcja konfucjańskiej demokracji, stanowiąca próbę odnalezienia nowych ram ideowych dla wzrastających w siłę państw „konfucjańskiego” Wschodu, była budowana w silnym przeciwstawieniu - także o wymiarze moralnym - do idei politycznych Zachodu, z demokracją rozumianą jako „władza ludu” na czele. Ren ben zhu yi (人本主義) - doktryna zakorzenienia władzy w ludzie, przeciwstawiana była stanowczo ren min zhu yi (人民主義) demokracji jako „władzy ludu” - opartej na abstrakcyjnej, izolowanej jednostce, niezapośredniczonej w stosunkach społecznych. Demokracja jako „władza ludu” w swym zachodnim wydaniu miała ignorować ważność struktur, poprzez które rozwija się jednostka. Co więcej, zdawała się wytwarzać sztuczną opozycje pomiędzy władzą a społeczeństwem doprowadzając tym samym do alienacji, osamotnienia, zagubienia ludzi Zachodu - ,samotność i porzucenie jednostek staje się pożywką dla lekkomyślności, pustki i braku nadziei”'4. Konstruowanie nowej legitymacji dla współczesnych rządów Azji oraz próba wyjaśnienia ich sukcesów odbywało się więc poprzez poszukiwanie takich elementów tradycji, które mogłyby wejść w zwycięski dialog z liberalną demokracją - rozumianą jako kultura Zachodus.

Algorytm tworzenia nowej tożsamości politycznej, opartej na rodzimych tradycjach rządzenia, nawiązujących krytyczny dialog z myślą społeczno-politycz-

\footnotetext{
${ }^{2}$ Chua Beng-huat, Consumption in Asia, Lifestyles and identities, Routledge 2000, s. 9.

${ }^{3}$ M. D. Barr, Cultural politics and Asian values, Routledge 2002, s. 6.

${ }^{4}$ Huang Chun-chieh, Wu Kuang-ming, Taiwan and the Confucian aspiration:Toward the twenty-first century, [w:] Cultural change in postwar Taiwan, red. S. Harell, Huang Chun-chieh, 1994, s. 83 .
}

${ }^{5}$ M. D. Barr, op.cit. s. 5. 
ną Zachodu, przynoszący rezultaty w postaci np. wspomnianej wyżej „demokracji konfucjańskiej”, zyskał ważność nie tylko na przecięciu refleksji filozoficznej i społecznej, ale, przede wszystkim, jak wspomnieliśmy, w realnym życiu politycznym krajów Azji Wschodniej. Szczególny rozgłos zyskała koncepcja skłonna rozszerzyć opozycje ,indywidualistycznego, liberalnego Zachodu” i „wspólnotowego, szanującego strukturę społeczeństwa Wschodu" na Zachód i Azję Wschodnią tout court. Koncepcja wartości azjatyckich, bo o niej mowa, przedstawiała różnice pomiędzy obydwoma kręgami kulturowymi w perspektywie sekwencji opozycji wynikających z opozycji naczelnej pomiędzy indywidualizmem Zachodu a komunitaryzmem i solidaryzmem Wschodu. Przejęta przez dyskurs polityczny, zyskała, podobnie do konstruktu demokracji konfucjańskiej, wyraźny rys moralistyczny. W oczach politycznych orędowników wartości azjatyckich indywidualizm Zachodu nie jest rozpatrywany już jedynie w aspekcie politycznym - mówi się o nim w kontekście wartości właśnie - co pozwala na jeszcze śmielszą ocenę moralną. Dr Mahathir bin Muhammad ${ }^{6}$, były premier Malezji i czołowy orędownik wartości azjatyckich tak pisze o wartościach Zachodu ostatnich lat: „Plenią się materializm, gratyfikacja zmysłowa i egoizm. Społeczność ustąpiła pierwszeństwa jednostce i jej pragnieniom. Nieuniknione konsekwencje to upadek ustanowionych instytucji, mniejszy szacunek dla małżeństwa, wartości rodzinnych, osób starszych, ważnych zwyczajów, konwencji i tradycji"’ .

Entuzjastyczne powitanie idei wartości azjatyckich przez polityków regionu mogło być - i było - rozpatrywane przez obserwatorów na wielu poziomach: jako poszukiwanie przez elity władzy nowego wymiaru tożsamości w perspektywie osiągniętego sukcesu i nowoczesności, jako próbę wypracowania narzędzia przeciwko liberalnej demokracji niszczącej wschodnie społeczeństwa, oraz jako próbę wypracowania narzędzia przeciwko liberalnej demokracji w... obronie autorytarnych rządów ${ }^{8}$.

Z dzisiejszej perspektywy można oceniać, że przeprowadzone w roku 1994 badania D. J. Hitchcocka, przedstawione w publikacji Asian Values and the United States: How Much Conflict?, a zwłaszcza ich późniejsza, entuzjastyczna interpretacja dokonana przez azjatyckie kręgi polityczne, osadzone były silnie we wspomnianym wyżej dyskursie opartym na przeciwstawieniu Wschodu i Zachodu i poszukiwaniu rodzimego charakteru przyczyn sukcesu ekonomicznego. Badania, $\mathrm{w}$ formie krótkiego kwestionariusza zaprezentowanego badanym z 7 krajów Azji Wschodniej oraz ze Stanów Zjednoczonych, którego pytania przedstawione zostały poniżej (tab.1), miały za zadanie określić szczególny wymiar rzeczywistości społecznej i politycznej dla danych społeczeństw, jakim jest ich system wartości.

\footnotetext{
${ }^{6}$ Częściej stosuje się formę nazwiska: Mahathir bin Mohamad - od red.

${ }^{7}$ M. D. Barr, op.cit., s. 43.

${ }^{8}$ Por. D. A. Bell, op.cit., s. 3; M. D. Barr, op.cit, s. 5.
} 
Badanych pytano o „najważniejsze w ich społeczeństwie wartości indywidualne i społeczne". Wartości uznane za atrybuty liberalizmu, zarówno w jego społecznym, jak i osobistym wymiarze (np. „rozstrzyganie sporów politycznych na drodze otwartej debaty” czy „samorealizacja”), zostały zestawione z wartościami, jak się zdawało, niesionymi przez azjatyckie tradycje (np. ,rozstrzyganie sporów politycznych na drodze prywatnych konsultacji” czy „,posłuszeństwo rodzicom”).

Tabela 1.

Badania D. I. Hitchcocka - zestawy wartości społecznych i osobistych

\begin{tabular}{|c|c|}
\hline Social values & Personal values \\
\hline $\begin{array}{ll}- & \text { respect for authority } \\
- & \text { decision by majority } \\
- & \text { preserve harmony for the group } \\
- & \text { orderly society } \\
- & \text { rights of society } \\
- & \text { personal freedom } \\
- & \text { open to new ideas } \\
- & \text { rights of the individual } \\
- & \text { consensus } \\
- & \text { accountability of public officials } \\
- & \text { resolve conflicting political views } \\
& \text { through private consultation } \\
- & \text { thinking for oneself } \\
- & \text { freedom of expression } \\
- & \text { resolve conflicting political views } \\
& \text { through open debate }\end{array}$ & $\begin{array}{ll}- & \text { self-reliance } \\
- & \text { hard work } \\
- & \text { respect for learning } \\
- & \text { honesty } \\
- & \text { obedience to parents } \\
- & \text { helping others } \\
- & \text { follow religious teachings } \\
- & \text { self-discipline } \\
- & \text { inner self-fulfillment } \\
- & \text { personal achievement } \\
- & \text { fulfilling obligations to others } \\
- & \text { achieving success in life }\end{array}$ \\
\hline
\end{tabular}

Wyniki sondażu (tabela 2 i 3) potwierdziły w zdecydowany sposób wizje nie tylko teoretyków i praktyków „,konfucjańskiej demokracji”, ale i coraz śmielszych głosów orędowników wartości azjatyckich, którzy zasięg opozycji na linii ,indywidualizm” - „wspólnotowość" (rozszczepionych na poszczególne diady tej opozycji) skłonni byli rozszerzyć poza relację liberalny Zachód - kraje kręgu konfucjańskiego, na kraje Azji wschodniej tout court. Do orędowników spoza kręgu konfucjańskiego możemy zaliczyć np. jedną ze znamienitszych postaci współczesnej polityki malezyjskiej, wspomnianego już dr Mahathira bin Muhammada.

Choć w dyskursie zaangażowanym politycznie, a dotyczącym Azji Wschodniej w latach 90., a także w dużej mierze i teraz, kategorie binarne generalizowanego Wschodu i Zachodu mają wciąż istotne znaczenie, to jednak nawet pobieżna analiza historii poszczególnych krajów i terytoriów regionu wskazuje, że rzadko kiedy opozycja Wschodu i Zachodu kształtowała w znaczący sposób „wyobraź- 
nię społeczną" (idee w wyobraźni społecznej nie wynikają automatycznie ani ze stosunków ekonomicznych ani nawet politycznych. Stąd nawet bardzo istotna rola np. państw Zachodu kolonizujących region Azji Wschodniej, czy zimnowojenna obecność Stanów Zjednoczonych w niektórych państwach obszaru nie przesądza bynajmniej o wykształceniu się opartej na wspomnianym przeciwieństwie percepcji społecznej). Co więcej, wydaje się, że czasy współczesne również nie dają zasadniczo podstaw do rozpatrywania zjawisk ze sfery kultury jako dających się interpretować poprzez pryzmat kategorii „Zachodu” i ,azjatyckości”. Czy zatem opozycja ta może być jeszcze adekwatnym narzędziem do analizowania przeszłości i teraźniejszości?

Tabela 2.

Wyniki badań Davida I. Hitchcocka, wartości osobiste

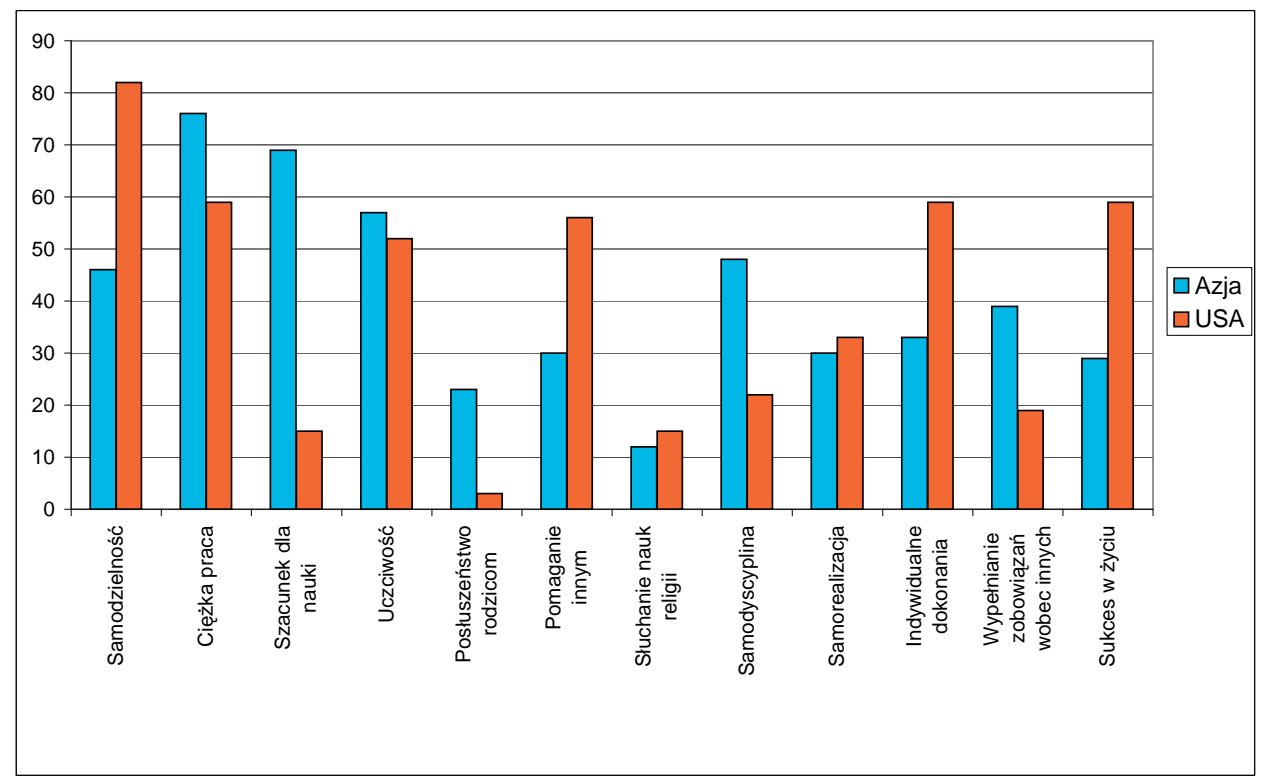


Tabela 3.

Wyniki badań Davida I. Hitchcocka, wartości społeczne

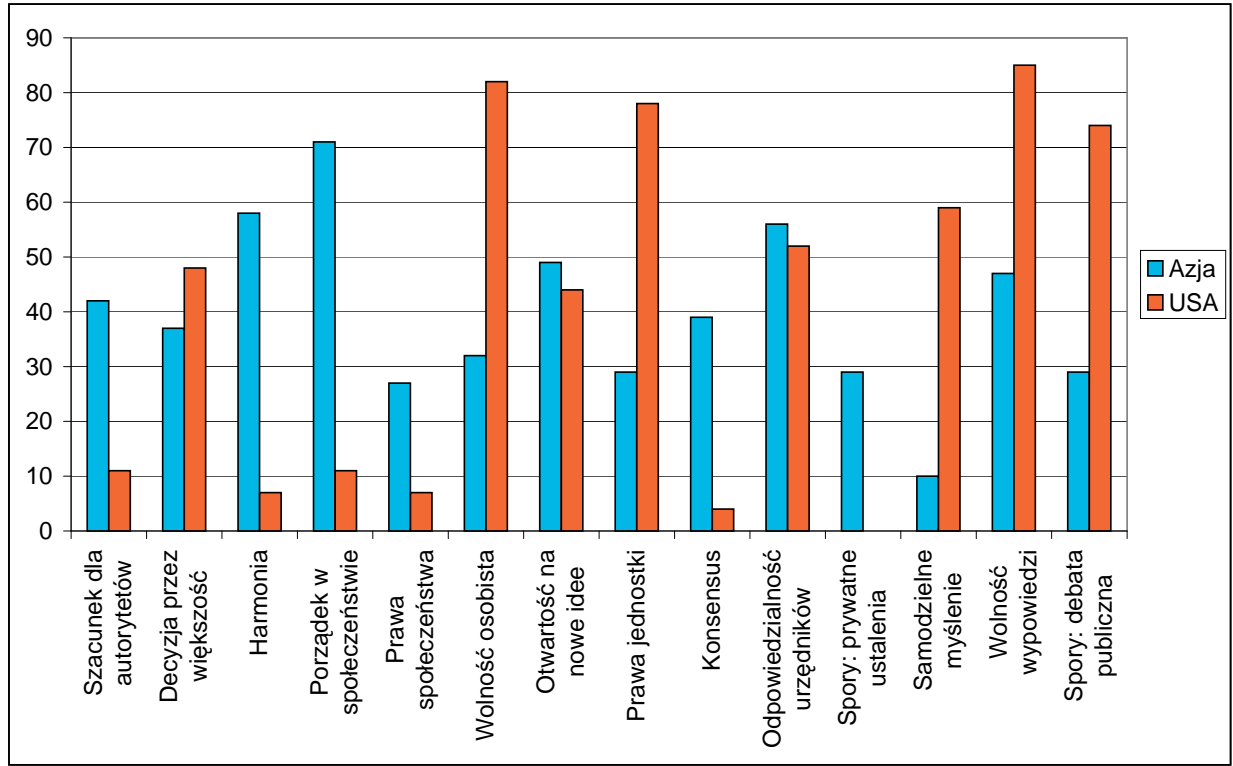

Warto w tym momencie, jak sądzę, naszkicować krótko historyczny rys opozycji, które faktycznie organizowały w przeszłości kulturę regionu, którego systemem wartości pragniemy zająć się w niniejszym opracowaniu, czyli Tajwanem. Pozwoli to nam, jak sądzę, na ostrożniejsze traktowanie wyników przeprowadzonego badania.

Przykład Tajwanu, którym zajmiemy się poprzez perspektywę przeprowadzonych przez nas badań, wskazuje, że percepcja społeczna dotycząca systemu wartości jak i kultury jako takiej w toku historii Tajwanu nie była bynajmniej organizowana według opozycji tego, co wschodnie i co zachodnie. Co więcej również czasy współczesne, teoretycznie obfitujące w sytuacje spotkań elementów Wschodu i Zachodu, w praktyce ukazują, że rozumienia charakteru ich spotkań nie da zbudować się na przeciwieństwach. Obserwowanych fenomenów, nawet jeżeli powiązanych z oddziaływaniem pewnych wzorów kultury Zachodu, nie da się również wytłumaczyć ani w kategoriach „okcydentalizacji”, ani ,,adaptacji”.

Wydaje się, że wprowadzenie tych uwag, popartych poniższymi kilkoma przykładami, ma zasadnicze znaczenie dla interpretacji wyników przeprowadzonego badania, tym bardziej, że wykorzystuje ono kwestionariusz D. J. Hitchocka.

Jak zauważają Stevan Harell i Huang Chun-chieh' ${ }^{9}$, historię i percepcję społeczną Tajwanu faktycznie organizowały często różnego rodzaju przeciwstawienia i na-

\footnotetext{
${ }^{9}$ Por. Cultural change..., s. 2.
} 
pięcia pomiędzy tym, co lokalne a tym, co obce, zewnętrzne. Dystynkcja ta, wedle wspomnianych badaczy stanowi adekwatne narzędzie analizy począwszy od historycznego rozróżnienia ludności wyspy na rdzennych mieszkańców, obecnie zwanych aborygenami, którym współcześnie przypisuje się korzenie malajskie, i emigrantów, masowo napływających od XVI w. z chińskiego kontynentu, zwłaszcza z naprzeciwległej względem Tajwanu prowincji Fukien. Opozycja zyskać miała nowy wymiar wraz z pojawieniem się holenderskich władz kolonialnych, które nie zaskarbiły sobie przychylności ludności pochodzenia chińskiego. Sam konflikt chociaż przebiegał wedle kryteriów etnicznych pomiędzy ludnością chińską a władzą holenderską - nie miał jednak bynajmniej wymiaru konfliktu kulturowego, ani tym bardziej charakteru ,zderzenia cywilizacji”, gdyż organizowany był na o wiele niższym poziomie - jako, że cele Holendrów wobec wyspy nie wykraczały poza doraźne cele ekonomiczne (z wyjątkiem chrystianizacji ludności aborygeńskiej). Osią sporu pozostała wysokość nakładanego na ludność chińską podatku.

Także okres panowania dynastii Qing, przypadający na Tajwanie na lata 1683-1895 , nie był wolny od konfliktu. Czas ten, początkowo naznaczony przybyciem na wyspę lojalistów obalonej przez Mandżurów dynastii Ming z Koxingą na czele - był czasem częstych buntów i braku zgody. Lojaliści mingowscy nigdy nie uznali „obcej” dynastii jako legalnej władzy. Zażegnania konfliktu nie ułatwiała sama administracja dynastii Qing - Tajwan, traktowany jako ekonomiczne i kulturowe peryferie imperium, będący obiektem nadużyć i wyzysku w postaci chociażby nadmiernie wysokich podatków.

Modernizacja wyspy również nie miała bynajmniej twarzy Zachodu - pierwsze, choć stosunkowo niewielkie zmiany dotyczące modernizacji produkcji, wprowadzenia nowoczesnych środków transportu zostały powzięte już pod koniec panowania dynastii mandżurskiej, zaś właściwy impet uzyskały dopiero wraz z przekazaniem Tajwanu Cesarstwu Japońskiemu - przeżywającemu modernizację ery Meiji. Nowoczesność produkcji, rozwój przemysłu i postępujące wraz z nim procesy np. przemian w obrębie rodziny, choć mogące być do pewnego stopnia przyrównane do przemian wynikłych na Zachodzie Europy podczas rewolucji industrialnej - takich jak indywidualizacja pracy, związana z oddzieleniem miejsca pracy od miejsca zamieszkania, czy utrata monopolu rodziny na wiedzę związana z rozwojem szkolnictwa, nie były historycznie powiązane z Zachodem i jego bezpośrednią aktywnością, tylko z procesem modernizacyjnym jako takim - stąd modernizacja okresu japońskiego również nie wnosi do percepcji społecznej opozycji Wschodu i Zachodu jako znaczącej.

Czy pojawia się ona po 1945? Choć niewątpliwie wraz z powrotem wyspy pod administrację chińską, w szczególnych warunkach politycznych, Zachód i jego kultura pojawia się jako znaczący Inny, to jednak - jak się wydaje - po roku 1945 nastąpił okres, który w sposób daleko ważniejszy ukształtował kulturę i systemy wartości obecne na wyspie. 
Rozstrzygnięcia kończące drugą wojnę światową nakazują Japonii zwrot Formozy pod administrację chińskiej władzy legalnej - wówczas Republiki Chińskiej. W ostatnich latach coraz częściej pojawiają się głosy, że powrót do Chin, początkowo postrzegany przez mieszańców wyspy jako powrót do ojczyzny, szybko stał się przyczyną rozczarowań, zwłaszcza, że rząd nacjonalistyczny z podejrzliwością traktował mieszkańców Tajwanu mających za sobą ponad 50 lat ,japonizacji” jako „niedostatecznie chińskich" ${ }^{10}$. Wzajemna podejrzliwość już w niecałe dwa lata po przejęciu wyspy 28 lutego 1947 przez Republikę Chińską stała się przyczyną tragedii, która zantagonizowała przybyszy i autochtonów na wiele lat.

Ewakuacja w 1949 r. z kontynentu na Tajwan armii Chiang Kai-sheka oraz personelu wojskowego i administracyjnego, w ogólnej liczbie ok. 2 mln osób, cofających się przed oddziałami komunistycznymi, przewartościowała na dobre dyskurs społeczny. Uwydatniła mianowicie opozycję pomiędzy napływającymi na Tajwan od wielu wieków, pochodzącymi przeważnie z prowincji Fukien mieszkańców wyspy określanych jako ben sheng ren (本省人, dosłownie - ludzie z „tej prowincji”) a przybywającymi na wyspę oddziałami wojsk kuomintangowskich i personelu wojskowego - wai sheng ren (外省人, czyli ludzie z obcej prowincji). Opozycję tę uwydatniał dodatkowo charakter struktury władzy - podział na rządzących i rządzonych przebiegał według opozycji pomiędzy mieszkańcami wyspy a przybyszami z roku 1949. Objęcie kontroli nad kulturą prawomocną i sferą symboli i historii na wyspie przez nacjonalistów uwydatniło różnicę pomiędzy dotychczasowymi mieszkańcami wyspy, a władzami - posługującymi się retoryką tradycji wielkich Chin oraz obawiającymi się abstrakcyjnego dla mieszkańców Formozy zagrożenia komunizmem. Sam proces powtórnej „sinizacji”, konieczny, jak podkreślano, ze względu na ,japonizację”, która miała się dokonać podczas japońskiej kolonizacji, przejawiający się chociażby w organizacji systemu edukacyjnego (odtąd posługującego się wyłącznie językiem mandaryńskim), jakiemu poddani zostali mieszkańcy wyspy - uwydatniał dramatyczną opozycję. Dokonanie dystynkcji na prawowitych spadkobierców tradycji chińskiej i „,niepewną ideologicznie" ludność Tajwanu było konieczne do rozpoczęcia procesu jej znoszenia w imię donioślejszej jeszcze opozycji o wymiarze politycznym. Nacisk na rekonstruowanie tradycji chińskiej na Tajwanie odbywał się bowiem w warunkach zagrożenia politycznego i militarnego ze strony formujących się na kontynencie Chin ludowych - odtąd w sferze symboli przedstawianych przez nacjonalistyczny rząd na Tajwanie jako zaprzeczenie „chińskości” i tradycji.

Konieczność walki ideologicznej sugerowała Tajwanowi druga jeszcze, oprócz chińskiej tożsamości - tożsamość nowoczesnego, wykazującego sukcesy ekonomiczne państwa. Podczas gdy Rewolucja Kulturalna symbolicznie i dosłownie

${ }^{10}$ Chen Yueh-ying, Social change and collective memory: Taiwan's two pasts, (dysertacja doktorska), Athens Georgia 1998, s. 41. 
niszczyła pozostałości denuncjowanego jako ideologia imperialistyczna konfucjanizmu na kontynencie, na Tajwanie rząd kuomintangowski popierał neokonfucjanizm - chociażby reprezentowany w postaci ruchu „Nowy Renesans” - Xin Sheng (新生), lub też jako nastawienie dominujące w szkolnych treściach edukacyjnych. Wspierany (neo)konfucjanizm jawił się jako ideologia z jednej strony tradycyjna, a z drugiej mogąca, w przeciwieństwie do komunizmu, sprostać wymaganiom nowoczesnego państwa ${ }^{11}$. Nowoczesność, industrializacja i urbanizacja nie tylko więc nie stanowity antytezy tradycji, lecz miały być przez nią napędzane, sugerując - także światu zewnętrznemu - przewagę tradycyjnych struktur myślenia nad systemem komunistycznym. Wynikła z podziału zimnowojennego konieczność współdziałania rządu nacjonalistycznego ze Stanami Zjednoczonymi widzącymi w Tajwanie bramę świata zachodniego na Wschodzie i ważnego partnera w walce z komunizmem, przyczyniła się do paradoksalnej z perspektywy modernistycznej sytuacji, gdzie nowoczesność, o bardziej zachodnim teraz już wymiarze, nie tylko nie stanowiła przeciwstawienia dla chińskiej „tradycji”, ale miała być w niej ufundowana. Pośrednio nowoczesność miała być środkiem do obrony „tradycji” i jej ideologicznego uzasadnienia.

Sukcesy tajwańskiej gospodarki lat $70 . \mathrm{z}$ jednej strony utrwaliły przekonanie, że koegzystencja tradycji chińskiej o silnych cechach konfucjańskich oraz sukcesu ekonomicznego jest nie tylko możliwa, ale wręcz sam sukces ekonomiczny może być warunkowany kulturami odmiennymi od kultury liberalnej demokracji - w tym przypadku kulturą (neo)konfucjańską Chin. Jednocześnie to właśnie w latach 70. izolacja Republiki Chińskiej na arenie międzynarodowej i odmówienie jej prawa do reprezentowania Chin na arenie międzynarodowej na rzecz ChRL, ponownie pozostawiła kulturę wyspy na rozdrożu. Redefiniowaniu podlegać poczęła nie tylko tradycja wielkich Chin, ale i perspektywa postrzegania Tajwanu - niekoniecznie traktowanego jako peryferie kultury chińskiej, ale jako miejsca kultury osobnej i nieredukowalnej do lokalnej odmiany kultury Państwa Środka.

Choć powojenny Tajwan w dużej mierze otwiera się na produkty i style życia oferowane przez kulturę zachodnią, a zwłaszcza amerykańską, propagowaną intensywnie np. w latach 50. za sprawą obecności wojsk amerykańskich, to jednak jej wpływ na przemiany kulturowe na wyspie jest dużo bardziej skomplikowany niż proces, który można by określić popularnym mianem westernizacji, czy - z racji szczególnych stosunków Tajwanu i USA w okresie zimnej wojny - amerykanizacji. Niestety, bardzo niewiele opracowań podejmuje próbę ukazania mechanizmów wpływu konkretnych ośrodków czy produktów kultury amerykańskiej na kształt przemian kulturowych na Tajwanie czy też przemian systemu wartości. Przyczyną tego stanu rzeczy wydaje się panujące do niedawna przekonanie o oczywistości

${ }^{11}$ Por. A. Chun, An oriental orientalism: the paradox of tradition and modernity in nationalist Taiwan, „History and anthropology” 1995, nr 1, s. 27-56. 
zastosowania schematu amerykanizacji do analizowania relacji wytworów kultury amerykańskiej i rzeczywistości społecznej Tajwanu ${ }^{12}$. Tymczasem obecnie prowadzone badania nad międzykulturową konsumpcją ${ }^{13}$ ukazują złożoność procesu adaptacji produktów pochodzenia obcego $\mathrm{w}$ danych lokalnych warunkach. Założenie o aktywności konsumentów w negocjowaniu sensu produktu, leżące u podstaw teorii hybrydyzacji czy kreolizacji, nie pozwala na zbyt łatwe przyjęcie tezy o westernizacyjnej funkcji produktów zachodnich. Produkty przeniesione do kultury innej niż rodzima mogą zyskać zupełnie odmienne funkcje i tożsamości ${ }^{14}$ zaś ich nabywanie bądź używanie przez odbiorców z innej kultury nie musi świadczyć o upodabnianiu się wzorców konsumpcji do wzorców zachodnich czy wręcz amerykańskich ${ }^{15}$.

Wiele przykładów z historii i współczesności tajwańskiej i - szerzej - wschodnioazjatyckiej kultury popularnej wskazuje, że charakter zmian, jakie przynoszą produkty i style życia Zachodu, nie tylko często nie współgra ze schematem „wypierania" wartości tradycyjnych przez nową rzeczywistość, ale często wobec tego rodzaju perspektywy ma charakter wręcz paradoksalny. Jak ukazują prace badaczy tematyki tajwańskiej i wschodnioazjatyckiej, często analogie pomiędzy wartościami czy sposobami działania „zachodnimi” a przyjętymi przez mieszkańców wyspy są powierzchowne i iluzoryczne - znajome dla zachodniego oka formy zachowań, wynikające z przemian modernizacyjnych (a nie okcydentalizacyjnych!) na wyspie czy z przyswojenia zachodnich produktów, często okazują się w rzeczywistości wręcz utrwalać istniejące już wcześniej wartości i zachowania, służyć innym, niż spodziewane przez zachodnie oko, celom.

Klasyczny już przykład takiego mechanizmu ukazuje studium J. L. Watsona dotyczące charakteru obecności MacDonaldsa w krajach Azji Wschodniej ${ }^{16}$. MacDonalds, jak podkreśla Watson, w przeważającej części Azji Wschodniej utracił współcześnie swój wydźwięk symboliczny, jaki chciałby w nim widzieć sam Zachód. Wraz z procesami globalizacji restauracja przestała być traktowana jako „oaza” kultury zachodniej czy też jako „nośnik” racjonalizacji obejmującej sferę odżywiania. W miarę dostosowywania do potrzeb lokalnych restauracje MacDonaldsa wyposażane były przez odwiedzających $\mathrm{w}$ inne niż nadane im początkowo przez założycieli znaczenia - stawały się miejscem spotkań rodzinnych, swego

${ }^{12}$ Por. Zhang Wei-bin, Taiwan's modernization. Americanization and modernizing Confucian manifestations, World Scientific Publishing, 2003.

${ }^{13}$ Por. Koichi Iwabuchi, Recentering globalization, Popular culture and Japanese transnationalism, Duke University Press, 2002; D. Howes, Cross-cultural consumption: Global markets, Local realities, Routledge 1996; S. Niessen, A. M. Leshkowich, C. Jones, Re-orienting fashion, the globalization of Asian dress, Oxford New York 2003.

${ }^{14}$ Por. U. Hannerz, Transnational connections: culture, people, places, Routledge 1996.

${ }^{15}$ Por. D. Miller, Young and restless, [w:] E. Hirsch, R. Silverstone (red.), Consuming technologies: media and information in domestic spaces, Routledge 1992.

${ }^{16}$ J. L. Watson, Golden Arches East, Stanford 1997. 
System wartości na Tajwanie

rodzaju czytelniami dla uczniów i studentów przeludnionych miast, gdzie trudno znaleźć spokojny kąt do nauki. Zaczęły być postrzegane jako fenomen lokalny, nie zaś obcy, zachodni. Jak zauważa Watson i jego współpracownicy, często nadawane restauracji przez azjatyckich konsumentów funkcje czy sensy były wręcz paradoksalne z punktu widzenia pierwotnych celów restauracji - zracjonalizowany, zhomogenizowany, mający być miejscem szybkiego posiłku Macdonalds stawał się np. miejscem przeciągających się do późnych godzin spotkań nastolatków, traktujących restauracje jako obszar prywatny, wręcz „,domowy”.

Podobne procesy przedstawia Warren I. Cohen ${ }^{17} \mathrm{~W}$ odniesieniu do wybudowanego w 1983 roku pod Tokio Disneylandu. Park rozrywki, który miał początkowo dawać zwiedzającym podobne do wrażeń z zagranicznych wakacji poczucie obcowania $\mathrm{z}$ tym, co odmienne i egzotyczne, niedługo po powstaniu zrezygnował z serwowania zachodnich potraw na rzecz sushi i tempury, poczyniono też dalsze kroki mające na celu zniesienie różnicy i dostosowanie produktu do japońskiego smaku. Jak zauważa Cohen „ten wzór azjatyckiej kontroli, przekształcający produkty kultury amerykańskiej w własne, lokalne, powtarzany jest bez końca na obszarze całej Azji Wschodniej"18. Przykłady te podkreślają nie tylko, jak sądzimy, nieoczywistość związku procesów modernizacyjnych z procesami okcydentalizacyjnymi w Azji Wschodniej, ale pokazują też paradoksalny charakter przemian formy i style życia przejęte z Zachodu zatracają swój symboliczny charakter i wyposażane są w takie elementy, które byłyby pożądane przez lokalną społeczność, co może, z kolei, służyć jej utrwaleniu.

Wydaje się, że powyższe kilka uwag jest niezbędnym poprzedzeniem wyników przeprowadzonych przez mnie na Tajwanie badań dotyczących systemu wartości studentów wybranych uczelni Tajpej, zwłaszcza, że posłużyłam się kwestionariuszem opracowanym przez D. I. Hitchococka, osadzonym w pewnym szczególnym dyskursie politycznym i społecznym, posługującym się esencjonalistycznym w gruncie rzeczy ujęciem przeciwieństwa Wschodu i Zachodu ${ }^{19}$, a więc językiem w dużej mierze obcym historii wyobrażeń społecznych na Tajwanie, a także do pewnego stopnia nieadekwatnym w stosunku do współczesnych mechanizmów przemian kulturowych. Chociaż wyniki kwestionariusza będą w dużej mierze rozpatrywane z perspektywy modernizacyjnej - to jednak ze szczególnym uwzględnieniem problemu nieadekwatności podziału Wschód-Zachód oraz ze szczególną uwagą skierowaną na rozdzielność pojęcia modernizacji i westernizacji.

Refleksja nad szczególną rolą polityki prowadzonej na wyspie, zwłaszcza od drugiej połowy lat 40. XX wieku, poprzez odkrycie „tradycji” jako podlegającej konstruowaniu i rekonstruowaniu przez „nowoczesne” państwo, a także obserwo-

\footnotetext{
${ }^{17}$ W. I. Cohen, The Asian American century, Harvard 2002.

${ }^{18}$ W. I. Cohen, op.cit., s. 51.

${ }^{19}$ K. Iwabuchi, op.cit., s. 12.
} 
wany mechanizm utrwalania lokalnych wyobrażeń i zwyczajów poprzez formy przybyłe z Zachodu, sugeruje konieczność szczególnie rozważnego traktowania modernizacyjnego continuum od tzw. „tradycji” do „nowoczesności”. Jak staraliśmy się ukazać w oparciu o powyższe przykłady zarówno z historii, jak i współczesności Tajwanu, to, co „tradycyjne”, nie musi bynajmniej stanowić „kontynuacji przeszłości”. Fenomen z zakresu wyobrażeń społecznych, a do nich także zaliczam system wartości „,społecznych” i ,osobistych”, który wydaje się być świadectwem trwania tradycyjnych wzorów, w rzeczywistości może okazać się zaadoptowaną polityczną „rekonstrukcją przeszłości” bądź fenomenem wynikłym z sytuacji współczesnej.

Sama decyzja o posłużeniu się kwestionariuszem Hitchcocka była spowodowana m.in. chęcią porównania wyników uzyskanych badań z wynikami uzyskanymi w toku badania opartego na tym samym kwestionariuszu a przeprowadzonego przez zespół studentów IS UW w 2003 roku na 486-osobowej próbie studentów uczelni wietnamskich ${ }^{20}$. Porównanie to zostanie przedstawione w ostatniej części niniejszego opracowania.

Przedstawiane badanie studentów uczelni Tajpej zostało przeprowadzone w grudniu 2004 i styczniu 2005 na grupie 81 studentów dwóch uczelni- Taiwan National University (台灣大學) - największej i najbardziej renomowanej uczelni Tajwanu, oraz University of Political Sciences (政治大學) - uczelni równie znanej i niewiele ustępującej renomą pierwszemu z wymienionych ośrodków. Wiek badanych wahał się od 19 do 23 lat. Posłużono się kwestionariuszem autorstwa D. I. Hitchcocka przetłumaczonym na język chiński na potrzeby badania. Tłumaczenie - w celu możliwie najdokładniejszego oddania sensu angielskiego pierwowzoru było wielokrotnie konsultowane zarówno z badaczami społecznymi z kilku ośrodków naukowych w Tajpej, jak i w Polsce oraz ze studentami anglistyki Tajwańskiego Uniwersytetu Pedagogicznego (師範大學).

\section{Wartości indywidualne - indywidualne dokonania - wspólny cel}

Choć tradycja, jak zwróciliśmy uwagę we wstępie, podlega konstruowaniu i redefiniowaniu, także poprzez sferę polityczną, to jednak niemożliwe jest zawężenie rozumienia tradycji do bycia wytworem nowoczesności. Dzięki źródłom historycznym kształt panujących na Tajwanie w przeszłości stosunków społecznych i wynikający z nich sposób myślenia o rzeczywistości społecznej jest dość czytelny.

Wielokrotnie, zwłaszcza w toku dyskusji o procesach tajwanizacji wyspy, ożywają argumenty o luźnej przynależności przybywających na wyspę imigrantów

\footnotetext{
${ }^{20}$ A. Jelonek (red.), Wietnamczycy: systemy wartości, stereotypy Zachodu, Warszawa 2004.
} 
z kontynentu - dotyczy to zwłaszcza ludów hakka - 客家 ${ }^{21}$. Wydaje się jednak, że ściśle rolniczy, klanowy charakter wyspy z jej okresu przedindustrialnego zdradza przynależność do tradycji konfucjańskich Chin, który to wzór nie tylko został sprowadzony przez przybywających przez wieki falami imigrantów z prowincji Fujian, ale też mógł się rozwinąć i utrwalić w czasach przynależności wysp do imperium z okresu dynastii mandżurskiej.

Obraz kultury tradycyjnej Tajwanu, jako w dużej mierze tożsamej z kulturą imperialnych Chin, jest obrazem przeważającym w tajwańskich naukach społecznych, w których dominuje, jak się wydaje, podejście modernizacyjne. Cechą dystynktywną takiego rodzaju kultury byłaby więc agrarność oraz szczególna pozycja rodziny - nie tylko jako środowiska ekonomicznego i wychowawczego, ale jako podstawy postrzegania przez jednostki siebie i kosmosu. Jak podkreśla większość badaczy, wyobrażenia o strukturze rodziny nakazywały postrzegać ją jako łańcuch pokoleń daleko wykraczający poza teraźniejszość w kierunku zarówno przyszłości, jak i przeszłości. Ziemia uprawna, rozumiana jako dar przodków dla przyszłych pokoleń, była głęboko w tej strukturze zapośredniczona - praca wykonana na roli stanowiła poniekąd obowiązek wobec przeszłych pokoleń - nie tylko wyrażała szacunek dla darczyńcy, ale przede wszystkim zapewniała też utrzymanie i tym samym ciągłości rodziny - zapewniając tym samym przodkom cześć ze strony nadchodzących pokoleń, stanowiącą jedyny sposób na godne życie w zaświatach. Ziemia wzmacniała więzy nie tylko pomiędzy światem umarłych a światem żywych - wielopokoleniowe gospodarstwo wspólnie pracujące nad uprawą ziemi uznawane było za społeczny ideał i wyraz rodzinnego szczęścia. Praca - choć wymagała dużego wysiłku własnego - wykonywana była przez jednostkę w imieniu i dla rodziny, jako że dochody wielopokoleniowego gospodarstwa domowego - jia (家) - były wspólne. Jednostka więc zawdzięczała swe życie i utrzymanie rodzinie - zarówno w wymiarze dosłownym - z racji chociażby wspólności funduszy i wychowania, jak i metafizycznie - przodkowie bowiem mieli moc wpływania na losy potomka w zależności, czy okazywał on należny, wyznaczony przez ramy cnoty synowskiej xiao (孝) sposób.

Również alternatywny wobec pracy na roli model kariery urzędnika obecny w cesarskich Chinach, a więc i przez pewien czas na Tajwanie, był powiązany w szczególny sposób z rodziną. Wstąpienie na ścieżkę kariery urzędniczej wynikało z powziętej w gronie rodzinnym decyzji i wymagało od członków rodziny długotrwałego wsparcia adepta oraz łożenia nań rodzinnych funduszy. Nic dziwnego, że sukces osoby był zarazem sukcesem rodziny - i nie tylko jej żywych członków, ale i zmarłych, jako, że rozpowszechnione było przekonanie, że nie ma lepszego sposobu uczczenia przodków niż wybranie kariery urzędniczej i rozsławienie ich

${ }^{21}$ „Hakka” - w mandaryńskim ,, ke jia” oznacza dosłownie „gości”, zdradzając luźną przynależność tej grupy etnicznej do struktur społecznych i organizacyjnej Cesarstwa. 
nazwiska. Porażka w egzaminach okrywała hańbą nie tylko niedoszłego urzędnika, ale też i wspierającą go emocjonalnie i finansowo rodzinę oraz nazwisko i cześć przodków. Specyficzna wdzięczność i zobowiązanie wobec rodziny odczuwane przez dążącą do pozycji zawodowej jednostkę sprawiała, że sam sukces, choć niemożliwy do osiągnięcia bez własnej ciężkiej i wytrwałej pracy, w swym wymiarze psychologicznym i społecznym nie był postrzegany jako indywidualny - w znaczeniu indywidualizmu działań, jak i celów. Tak jak jednostka nie była rozpatrywana w oderwaniu od rodziny i warunków egzystencji - tak i sukces nie mógł być oddzielony od warunków, które umożliwiły jego zaistnienie - te zaś miały formę wielowymiarowego wsparcia rodzinnego. Nie mógł też być oddzielony od swych zasadniczych, powiązanych z rodziną, celów. Sukces stanowił więc formę długu zaciągniętego wśród żywych i umarłych oraz pochodną wysiłku wielu osób. Tak jak jednostka powiązana była z rodziną różnorodnością więzów i zależności, tak i jej sukces bądź porażka odzwierciedlała charakter tych powiązań.

Choć przemiana modernizacyjna, związana z nią mobilność nie tylko zawodowa, ale i geograficzna mogła w znaczący sposób poluźnić i - jak wskazują badania - faktycznie poluźniła ten wyjątkowy charakter związku indywidualnego sukcesu i obowiązku wobec rodziny - chociażby poprzez wprowadzony podczas okresu kolonialnego system edukacyjny nie oparty na powiązaniach rodzinnych oraz zmieniające się warunki pracy, to późniejszy charakter procesów modernizacyjnych, jak podkreślają Arland Thornton i Hui-Sheng Lin ${ }^{22}$, w znaczącym stopniu przywrócit rzeczywistości społecznej zasadnicze zapośredniczenie sukcesu indywidualnego w rodzinie. Jak zaznaczają wspomniani wyżej autorzy, powojenny charakter rynku faworyzował średniej wielkości firmy rodzinne - dysponujące pewnym kapitałem koniecznym do rozwoju technologicznego z jednej strony, a jednocześnie na tyle małe, że będące w stanie zachować elastyczność. Sukces jednostki nie mógł być, ponownie, teraz już w warunkach współzawodnictwa na rynku, oddzielony od sukcesu rodziny. Ciężka praca i indywidualne dokonania jednostki realizowane były ze względu na dobro firmy rodzinnej. Dobro i interes jednostki rozpatrywane mogły być - tak jak dawniej - przez pryzmat dobra rodziny.

Wydaje się, że także i dziś sukces, czy to zawodowy czy szkolny, zasadniczo pojmowany jest przez młodych Tajwańczyków jako zawdzięczany w dużej części rodzinie i osiągany w jej imię, zaś ciężka praca może być traktowana jako swego rodzaju obowiązek rodzinny.

${ }^{22}$ A. Thornton, Hui-Sheng Lin (red.), Social change and the family in Taiwan, Chicago 1994, s. 119 . 
Tabela 4. Badania studentów uczelni Tajpej, wartości osobiste

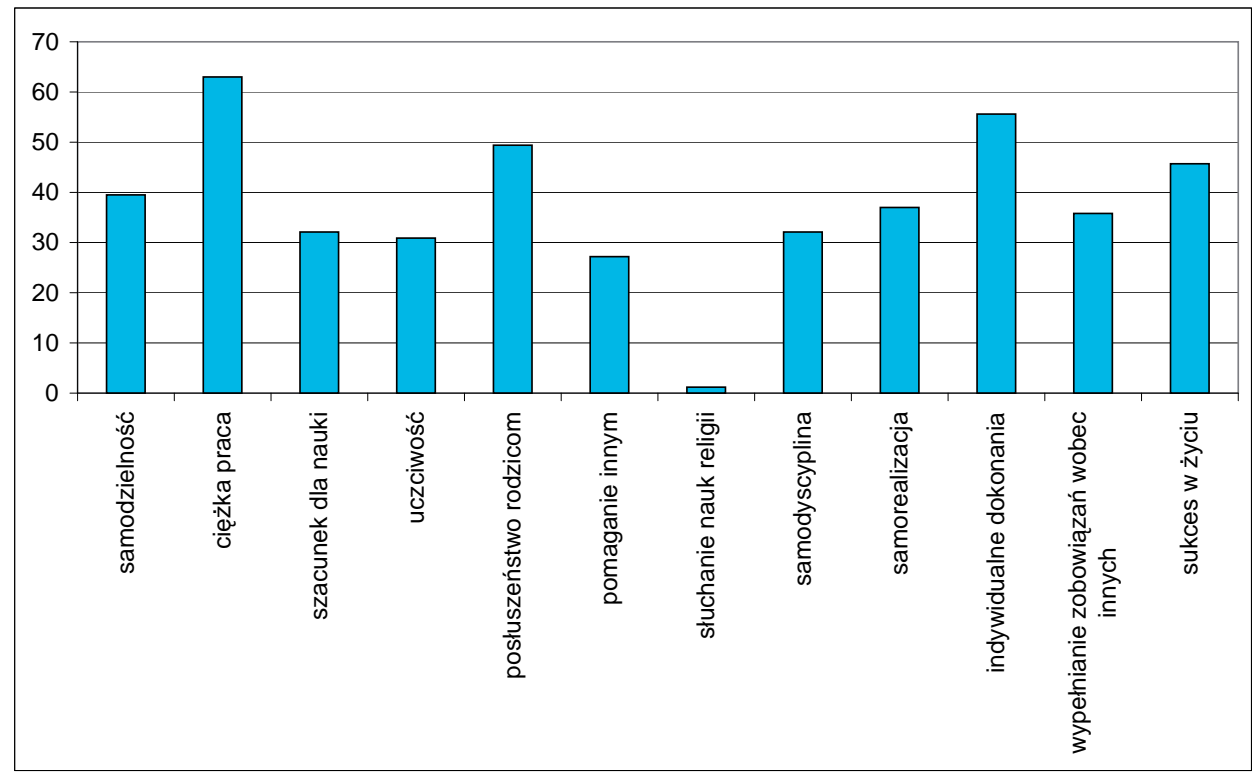

Znamienne, że po prześledzeniu indywidualnych odpowiedzi poszczególnych respondentów okazało się, aż $62,7 \%$ badanych, którzy wskazali ciężką pracę jako jedną $\mathrm{z}$ najistotniejszych wartości w społeczeństwie tajwańskim wskazało jako wartość istotną także i posłuszeństwo rodzicom ${ }^{23}$. Ciężka praca, która w pytaniu o wartości osobiste uzyskała najwyższy, bo $63 \%$ poziom wskazań, częściej współtowarzyszy uznaniu ważności „posłuszeństwa rodzicom”"24 niż chociażby uznaniu za istotną ,samorealizację" ${ }^{25}$, a nawet sukces ${ }^{26}$. Wyłaniający się poprzez pryzmat uzyskanych wyników obraz „ciężkiej pracy” ukazuje ją raczej jako wysiłek nie powiązany bezpośrednio z sukcesem jednostki, rozumianym tu dwojako - jako sukces wedle osobistych kryteriów (samorealizacja) oraz sukces rozumiany raczej jako pewne wyobrażenie społeczne („osiągnięcie sukcesu w życiu”). Wydaje się, że podobnie jak w przeszłości, ciężka praca powiązana jest z sukcesem jednostki w sposób pośredni - poprzez symbolizowaną przez rodziców rodzinę. Wypełnianie woli rodziny nie musi więc stać w sprzeczności z osiąganiem własnych celów - wręcz przeciwnie - może się stać ich ważną częścią. Posłuszeństwo rodzicom

${ }^{23}$ Test chi-kwadrat wskazuje na zależność istotną na poziomie, 002 .

${ }^{24} 62,7 \%$ studentów uznających społeczną wartość ciężkiej pracy uznało jednocześnie za ważne posłuszeństwo rodzicom.

${ }^{25}$ Jedynie $29,4 \%$ osób wskazujących na ważność „,ciężkiej” pracy wskazało jednocześnie na ważność „,samorealizacji”.

${ }^{26}$ Wśród osób deklarujących ważność ciężkiej pracy na ważność sukcesu wskazało 49\%. 
i dostosowywanie się do ich potrzeb czy wskazówek i ciężka praca są tym, co tworzy wartościowe życie i prawdziwy sukces jednostki - niezależny od własnego, subiektywnego odczucia (samorealizacja) oraz oceny dalszego otoczenia (odniesienie sukcesu w życiu).

O tym, że rola rodziny jest na Tajwanie szczególnie ważna, może świadczyć pośrednio wyraźna różnica we wskazaniach na „posłuszeństwo rodzicom”, jako wartość odnoszącą się do sfery rodziny, a na „pomaganie innym” - jako wartość odnoszącą się do sfery "innego" - nie powiązanego z jednostką więzami pokrewieństwa. Stosunkowo niewielu respondentów, bo jedynie $27,2 \%$, wskazało na społeczną ważność tej wartości.

Współczesny charakter postrzeganych przez studentów zależności pomiędzy rolą rodziny a pracą czy osiągnięciami jednostki nie musi być wyłącznie traktowany jako bezpośrednia kontynuacja stanu przeszłego. Jak sądzę, może zostać owocnie zanalizowany w toku chociażby analizy kształtu współczesnego systemu kształcenia na Tajwanie, jako że wobec dominującej roli procesu edukacyjnego w życiu młodych Tajwańczyków, to właśnie pryzmat edukacji kształtuje wyobrażenia młodych o „ciężkiej pracy” czy „sukcesie”.

Obserwowane dzisiaj jednoczenie się tajwańskiej rodziny w imię solidnego wykształcenia dzieci przyjmuje niezwykle intensywne formy. By sprostać szybkiemu tempu rozwoju wyspy i rosnącej konkurencji, rodzina, tym razem często ograniczona do rodziców i dziadków, nie szczędzi środków ani wysiłków, by zwiększać szanse dziecka na rynku pracy, a co za tym idzie, nadzieje jego rodziny na dostatnią przyszłość. Współczesny kształt edukacji szkolnej i pozaszkolnej na Tajwanie wymaga nie tylko wielkich nakładów finansowych, ale też czasu i uwagi poświęcanej wysiłkowi edukacyjnemu dziecka przez starszych. Świadomość poświęcania się rodziny dla dobra wykształcenia dziecka rodzi formę nowego długu wdzięczności - tym razem nie wobec dalekich przodków, którzy ofiarowywali swym następcom ziemię, ale wobec najbliższej rodziny.

Tymi szczególnymi stosunkami należy być może tłumaczyć dość dużą różnicę pomiędzy wskazaniami na istotność „ciężkiej pracy” a ważność „,polegania na sobie" (39,5\%). Młodzi najczęściej wydają się być świadomi, że polegać mogą nie tylko na sobie, ale też na strukturze rodzinnej, w której są zakorzenieni - wspomniana już „ciężka praca” jest być może swoistą formą wyrazu wdzięczności za otrzymaną pomoc. $Z$ pewnością relacja wskazań na te dwie wartości znajduje swe zakorzenienie we wspomnianej już szczególnej strukturze rynku pracy na Tajwanie - gdzie warunkiem sukcesu zawodowego nie jest bynajmniej „,poleganie na sobie” i niezależność, ale właśnie umiejętność konstruowania zależności czy to rodzinnej czy budowanej na wzór rodzinny oraz efektywnego w niej egzystowania.

We współczesnym Tajwanie, którego zarówno nowoczesne struktury edukacyjne, na które składa się już nie tylko odpowiedni do wieku rodzaj szkoły, ale i ogrom- 
na, rozbudowana struktura cram schools ${ }^{27}$, szkół językowych i kursów przygotowawczych mających charakter nieobowiązkowy, choć w praktyce powszechny, dziwić może zaskakująco niski odsetek wskazań na ,,szacunek dla nauki” (32,2\%) jako wartość istotną. Ten stosunkowo niski odsetek budzić także może zdziwienie w kontekście tradycji konfucjańskiej, przypisującej nadzwyczajna rolę nie tylko zdobywaniu wiedzy, ale też i poszanowaniu reprezentujących ją struktur - zwłaszcza w osobie nauczyciela. Jakie mogą być przyczyny zaskakującego kształtu deklaracji ważności nauki pośród młodych Tajwańczyków?

Nim zajmiemy się próbą wyjaśnienia tego zaskakującego wyniku, pragniemy przywołać wypadki, które w ostatnich latach poruszyły dogłębnie Tajwanem - mianowicie wstrząsające przypadki agresji uczniów, szczególnie szkół średnich, wobec nauczycieli. Podczas jednego z ostatnich tego typu wydarzeń cała klasa zaatakowała „zbyt srogiego" i „okrutnego” nauczyciela, by „dać mu nauczkę”. Kilka lat wcześniej opinią publiczną wstrząsnął przypadek nastolatka, który ciosem karate zabił nauczyciela podczas lekcji. Przypadki te wydają się szczególnie wstrząsające i niezrozumiałe w kontekście tradycyjnej chińskiej niedyskursywnej koncepcji nauki oraz wynikającej z niej szczególnej pozycji nauczyciela. W obrębie tego rodzaju koncepcji uczenie traktowane jest jako proces przyswajania pewnego stałego, zastanego zasobu wiedzy, nie wyłania się z dialogu pomiędzy uczniem a nauczycielem. Próba wszczęcia dialogu byłaby odczytana, zarówno przez starsze pokolenia nauczycieli, jak i ich uczniów, jako jednoznaczny objaw braku szacunku. Niedyskursywne podejście do wiedzy jak i do jej zdobywania widać wyraźnie w samym języku chińskim i jego wyrażeniach związanych z nauką - „uczyć się w danej szkole” - określane jako nian shu oznacza dosłownie „czytanie książek”, nauczanie zaś to jiao shu ,nauczanie książek, czy też tego, co w książkach”. Uczenie się do egzaminu bądź przygotowywanie na lekcje określane jest zaś powszechnie mianem bei shu ,uczyć się książki na pamięćc. Samo zaś słowo jiao - nauczanie, w jego współczesnej pisowni jest powiązane ze znakiem xiao - oznaczającym cnotę synowską. Znak „nauczanie” 教 składa się bowiem elementu „xiao” 孝 oraz „uderzenie” 女. 孝 xiào - składające się z pierwiastka „stary” 考 oraz dziecko 子 - oznacza respekt i poszanowanie starszych przez dziecko, zaś uderzenie - 支 uderzenie symbolizuje władzę nauczyciela nad uczniem.

Choć przedstawione wyżej przypadki agresji nie mogą być w żadnym wypadku bezpośrednio wiązane $\mathrm{w}$ ramach jednego wyjaśnienia $\mathrm{z}$ opisanym niskim od-

\footnotetext{
${ }^{27}$ Pod koniec maja 2001 na Tajwanie działało 8666 cram schools zarejestrowanych przez Ministerstwo Edukacji. Jednakże, jak przyznają same tajwańskie źródła rządowe, liczba cram schools działających bez wymaganej licencji jest znacznie wyższa. Źródło: http://www.gio.gov.tw/taiwan-website/5-gp/q\&a/page_13.htm. Obecnie szacuje się, że w roku 2000 blisko 55,14\% uczniów high schools, uczęszczało do cram school odbierając tam różne formy pomocy edukacyjnej. Źródło: www. ntpu.edu.tw/dafl/newsletter/newsletter012.pdf.
} 
setkiem wskazań na ,poszanowanie nauki” w przedstawionym badaniu, to wydaje się, że mogą one stanowić dwie krańcowe manifestacje jednego problemu - mianowicie kryzysu koncepcji nauki i procesu nauczania. Wydaje się, że we współczesnym Tajwanie szczególny rozdźwięk w aspekcie koncepcji uczenia się zachodzi pomiędzy pokoleniem 15-20-latków a ich rodziców i nauczycieli. Pokolenie rodziców doświadczyło szkoły jako jedynego, niepodważalnego źródła wiedzy o świecie. Wiedza ta zaś traktowana była jako niedyskursywna wiedza tout court. Brak dodatkowych źródeł wiedzy w postaci chociażby rozwiniętego systemu kursów dodatkowych, szkół językowych, i - nade wszystko - nowoczesnych środków komunikacji, powodował bezwzględne podporządkowanie się nauczycielowi, jako źródłu wiedzy i autorytetowi. Ścieżka kariery była jasna, zaś środki do jej osiągnięcia oczywiste. Wydaje się, że takie przekonanie rodziców wyniesione $\mathrm{z}$ młodości przejawia się $\mathrm{w}$ ich obecnych wymaganiach w stosunku do własnych dzieci. Oczekują oni od młodzieży posłuszeństwa nauczycielowi i wytrwałej pracy - jako jedynych warunków koniecznych do osiągnięcia sukcesu szkolnego. Pomoc rodziców przejawia się w zapisaniu mającego problemy szkolne dziecka na dodatkowy kurs przedmiotu sprawiającego kłopot oraz próby pomocy o charakterze naukowym w obrębie rodziny. Problem szkolny traktowany jest jednowymiarowo jako wynik niedostatecznego skupienia się na studiowanym przedmiocie. Innego rodzaju problemy, wynikające ze stopniowej utraty przez wiedzę charakteru niepodważalnego i bezwzględnie prawdziwego, a co za tym idzie, zmiana postrzegania osoby nauczyciela, nie napotykają na wsparcie ze strony rodziców - starający się sprostać wysokim rodzicielskim wymaganiom ${ }^{28}$ uczniowie, przeciążeni nauką z jednej strony, a widzący jej ograniczenia z drugiej, nie potrafią rozwiązać nękającego ich problemu. Stąd zdarzające się „doraźne” i porażające brutalnością próby rozwiązania trudnej sytuacji.

Dynamiczny rozwój prywatnych ośrodków nauki pozaszkolnej, choć ufundowany na tradycyjnym chińskim szacunku do nauki i uznaniu jej priorytetu w życiu młodego człowieka paradoksalnie najwyraźniej więc przyczynia się do obniżenia jej prestiżu. Uczenie traktowane jest instrumentalnie, jako środek do zdania egzaminów umożliwiających studia, a w konsekwencji zapewniający zasobną i co ważne, prestiżową przyszłość. W Wietnamie, w którym w rzeczywistości konfucjańskie koncepty szacunku dla nauki i jej instytucji wchodzą dopiero w fazę konfrontacji z nowoczesną konkurencją i systemem dokształcania (np. powszechne na

${ }^{28}$ Jak wskazują badania Ruth K. Chao i Stanleya Sue przeprowadzone w Stanach Zjednoczonych, tylko 36\% amerykańskich matek pochodzenia chińskiego było zadowolonych z osiągnięć szkolnych swoich dzieci, wobec $76 \%$ deklarujących zadowolenie matek amerykańskich. Autorzy stawiają też hipotezę, że prawdopodobnie w obrębie społeczeństw chińskich odsetek usatysfakcjonowanych matek byłby jeszcze niższy. R. K. Chao, S. Sue, Chinese parental influence and children's school success, [w:] Grownig up the Chinese way, Chinese child and adolescent development, red. Sing Lau, Chinese University Press, 1996, s. 102. 
System wartości na Tajwanie

Tajwanie szkoły języka angielskiego dla dzieci i młodzieży, których dynamiczny rozwój nastąpił w latach 80., rozpoczęły swój rozwój dopiero w kilku ostatnich latach), odsetek „szacunku do nauki” jako wartości istotnej społecznie jest dużo wyższy - wyniósł on $54,3 \%$.

Na nie mniejszą niż „najczęściej wymieniane wartości” uwagę zasługują również wartości wymieniane najrzadziej. Jak wskazuje tabela nr 2 „słuchanie nakazów religijnych" jednoznacznie zostało uznane przez badanych za wartość nieistotną społecznie. Sam przekład na język chiński anglojęzycznego „following religious teachings" napotkał problemy - jako najwyraźniej nieadekwatny do dominującej na Tajwanie koncepcji religii. Jak zaznaczają Li-shou Yang, Arland Thornton i Thomas Fricke, w latach 80. odsetek Tajwańczyków mieszkających na terenach wiejskich, uznających samych siebie za wyznawców tzw. „religii ludowej”, wynosił ponad $90 \%{ }^{29}$, zaś w tym samym czasie odsetek rodzin utrzymujących domowy ołtarzyk poświęcony przodkom wynosił w miastach ok. 80\%.

Sama religia ludowa, dogłębnie powiązana z życiem rodziny i lokalnej społeczności, nie ma charakteru zbioru skodyfikowanych nakazów, nie posiada też wyspecyfikowanych struktur ani funkcjonariuszy, a co z tym związane - nie ma też kanonicznych tekstów ani bazy, która wyznaczałaby linie ortodoksji. Religijne przekonania są w dużej mierze kształtowane przez praktykujących - brak jest ośrodka władzy religijnej, która ustalałaby wzorzec - zarówno pod względem rytuałów, jak i przekonań. Jeżeli można wyróżnić obecne w niej nakazy bądź zalecenia - takie jak oddawanie czci przodkom poprzez określone rytuały, okazuje się, że nie wynikają one ze źródła pochodzenia pozarodzinnego, religijnego - przynależą do sfery historii i teraźniejszości poszczególnej rodziny. Samo czczenie przodków ujmowane jest raczej jako manifestacja cnoty xiao - cnoty posłuszeństwa synowskiego, która, wedle koncepcji rodziny wiążącej swych członków więzami nierozerwalnymi przez śmierć, nakazuje okazywać szacunek i służyć również i zmarłym przodkom, niż jako „nakaz religijny”. Samo czczenie poszczególnych bóstw ma zaś charakter głęboko pragmatyczny - wiążący czczącego i bóstwo zasadą bliższą kontraktowi, nie zaś nakładający na oddającego cześć zobowiązania charakteru moralnego. Marginalny odsetek wskazań na wartość „posłuszeństwa nakazom religijnym" wskazuje pośrednio (wskazana jest tu jednak duża doza ostrożności), że przyjmowanie przez młodych innych niż tradycyjna religia chińska koncepcji religijnych bądź wyznań wyznaczających kod nakazów i zaleceń, w badanej grupie faktycznie nie wystąpił.

${ }^{29}$ Li-shou Yang, A. Thornton, T. Fricke, Religion and family formation in Taiwan, [w:] Family, religion, and social change, (red.) Sh. K. Houseknecht, J. G. Pankhurst, Oxford 2000, s. 143. 


\section{Konfucjańskie społeczeństwo bez konfucjańskiej władzy?}

Procentowy rozkład odpowiedzi na pytania drugiego bloku, obejmującego wartości społeczne ukazany został w tabeli 5.

Tabela 5. Badania studentów uczelni Tajpei, wartości społeczne

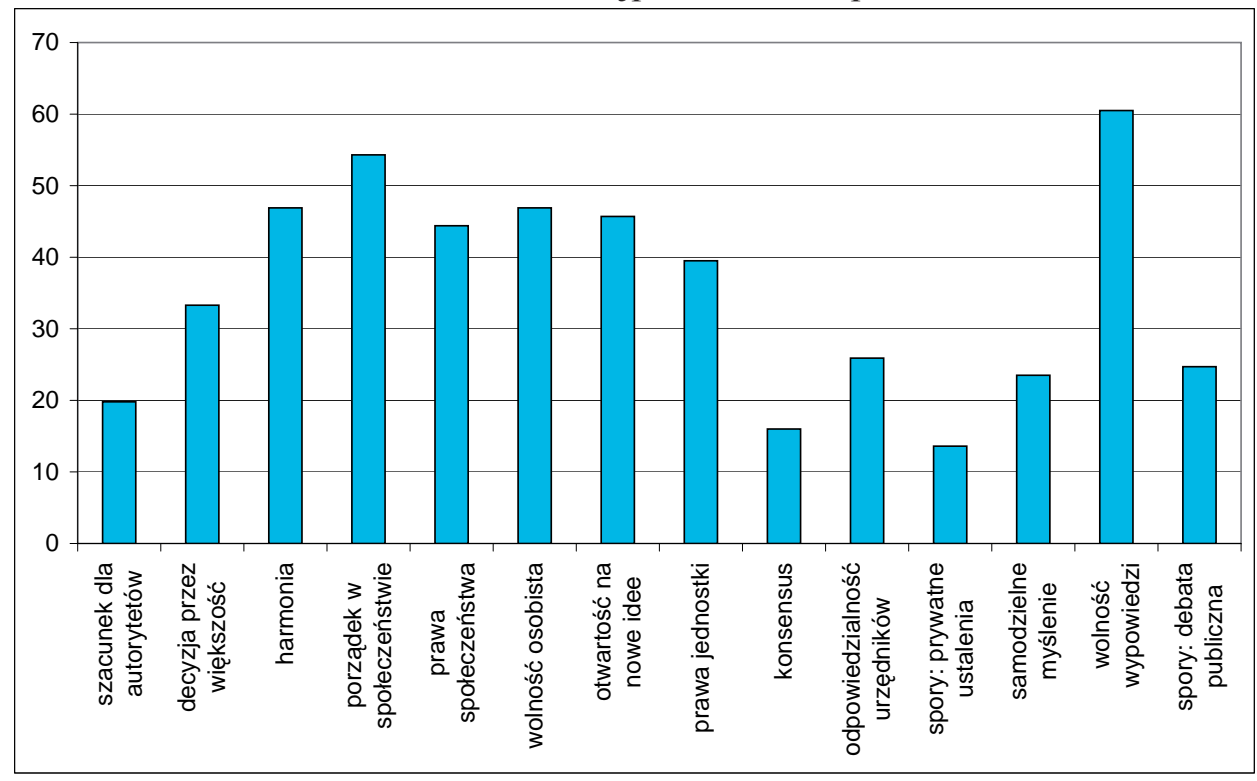

Poszanowanie dla władzy - znajdujące swą podbudowę tak w tradycji konfucjańskiej, jak i we współczesnym neokonfucjanizmie, jako dla siły pełniącej nadrzędną funkcję moralną w społeczeństwie - okazuje się mieć pośród badanych studentów wartość zaskakująco niską - 19\%. Porównanie z Wietnamem, gdzie odsetek osób deklarujących społeczną istotność szacunku dla władzy wyniósł 46\% oraz z badaniem Hitchcocka dla uogólnionej Azji Wschodniej (odsetek na poziomie $42 \%$ ), ukazuje drastyczną różnicę, lokując poziom poszanowania autorytetu władzy na Tajwanie bliżej poziomu badanych przez Hitchcocka Stanów Zjednoczonych (11\%), niż reszty państw regionu. Podobna sytuacja kształtuje się w perspektywie odpowiedzi na pytanie o istotność „odpowiedzialności urzędników panstwowych", z tym, że otrzymany wynik - $25,9 \%$ - jest niższy nie tylko od poziomu wskazanego przez badanie przeprowadzone w Wietnamie, ale także wobec obydwu badań Hitchcocka dla krajów Azji i Stanów Zjednoczonych.

Wynik ten stawia pozornie kuszącą hipotezę, że wprowadzenie funkcjonującej demokracji w kraju Azji Wschodniej może przyczyniać się do zaniku poszanowania władzy wiążącego się z utratą przez nią funkcji moralnej i przemiany koncep- 
cji władzy i społeczeństwa w kierunku wyznaczanym przez demokracje liberalne Zachodu. Z pewnością twierdzenie to zawiera w sobie część prawdy. Wśród moich rozmówców - szczególnie starszych - pamiętających rzeczywistość polityczną okresu autorytarnego Kuomintangu panuje przekonanie, iż negatywne zjawiska dotyczące sfery polityki w postaci korupcji czy przywłaszczania funduszy państwowych są wytworem ostatnich kilkunastu lat.

Prowadzący jeden z najbardziej popularnych tajwańskich talk show o tematyce politycznej „8 o'clock”, Yu Fu, tak thumaczy cel swego show: „Mój program to $[. .$.$] gra z politykami. Bierzesz jego (polityka) oficjalny wizerunek i bawisz się$ nim. Ponieważ to ich złości, zaczynają okazywać emocje. Ukazuje się ich prawdziwa twarz. Inaczej w telewizji starają się być tacy... głębocy, prawda? [...] Jakie więc jest moje zadanie? Ukazanie Wam ich prawdziwych twarzy"30. Koniec stanu wojennego w roku $1987 \mathrm{i}$ związane $\mathrm{z}$ nim zniesienie cenzury powoduje powstanie wolnych mediów prześcigających się $\mathrm{w}$, ukazywaniu prawdziwych twarzy polityków". Jeden, konsekwentnie budowany obraz sfery rządzącej zostaje zniszczony, zaś medialne wydarzenia ze sfery politycznej nagłośnione. Czy można jednak wnioskować, że nastanie demokracji i wolnych mediów spowodowało „okcydentalizację" sceny politycznej i jej percepcji?

Wydaje się, że w kontekście wyników naszych badań wniosek taki byłby nie tylko przedwczesny, ale i zbyt ogólny. Wydaje się, że dla wyjaśnienia obserwowanego fenomenu niskiego poszanowania władzy wśród młodych ludzi kluczowe znaczenie ma aktualna sytuacja polityczna na Tajwanie, nie zaś wzory o wysokim poziomie ogólności teoretycznej. Z przeprowadzonych przez mnie rozmów ze studentami uczelni Tajpej wynika, że przeżywają oni spadek zainteresowania polityką wyspy jako taką - najczęściej wymienianym powodem jest jej zorientowanie za sprawy „zewnętrzne”, obce rzeczywistym problemom i życiu młodych ludzi, jak i ich rodzin. Faktycznie, szczególna sytuacja międzynarodowa wyspy i konflikt z Chinami kontynentalnymi sprawiają, że to właśnie te problemy dominują w dyskursie politycznym - stosunek do kwestii niepodległościowej/unifikacji/status quo jest zaś naczelnym podziałem, wedle którego pragną identyfikować się tajwańskie naczelne siły polityczne. Stałe, wysokie zaangażowanie sceny publicznej w problem statusu politycznego wyspy przyczynia się do alienacji polityki i polityków głównych ugrupowań wobec życia i problemów młodych, których okres dorastania przypadł na czas, gdy problem kwestii statusu politycznego wyspy stawał się równie abstrakcyjny, co kwestia przynależności kulturowej do nigdy naocznie nie widzianych Chin kontynentalnych. Wydaje się więc, że niski odsetek szacunku do władzy uwarunkowany być może raczej szczególnym kształtem problemów międzynarodowych Tajwanu i ich roli w dyskursie politycznym, nie zaś wprowadze-

${ }^{30}$ D. K. Jordan, A. D. Morris, M. L. Moskowitz (red.), The minor arts of daily life: popular culture in Taiwan, University of Hawaii Press, 2004. 
niem samej demokracji i towarzyszącej jej rzeczywistości medialnej. Na rzecz tej hipotezy przemawiają wskazania badanych w odpowiedzi na inne pytania sondażu - niezwykle wysokie wskazania na , ,harmonię społeczną" - 46,9\%, ,porządek w społeczeństwie” - 54,3\% i „prawa społeczeństwa” - 44\%, znacznie ważniejsze niż „otwarta debata” - 24,7\%, czy „podejmowanie decyzji przez większość” - 33\% wskazują, że wyobrażenia młodych o wartościach społecznych daleko odbiegają od wizji społeczeństwa liberalnej demokracji. Obraz społeczeństwa wyłaniający się z badań, choć wskazujący na kryzys władzy i jej funkcji moralnej, jest obrazem społeczeństwa traktowanego jako nieredukowalna do „sumy wolności” organiczna całość organizowana na poszczególnych poziomach - rodzinnym (wysoki odsetek ważności dla „posłuszeństwa rodzicom”), międzygrupowym (,harmonia społeczna"), aż do strukturującego i mającego pewne konotacje polityczne „porządku w społeczeństwie” (you zhixiu de shehui - 有秩序的社會). Społeczeństwo wydaje się być całością w aspekcie moralnym - miejscem, gdzie powinna być realizowana harmonia i uporządkowanie. Nic dziwnego, że „otwarta debata”, jako bezpośrednia konfrontacja, nie uzyskała zbyt wysokiego odsetka wskazań. Jednak, jak wskazują badacze, zjawiska takie jak np. niezwykle dynamiczny rozwój politycznych call-in shows - swoistej odmiany politycznego talk-show, gdzie szczególne miejsce zajmują telefoniczne wypowiedzi widzów, zaś słowem-kluczem jest kaijiang - otwarte, bezpośrednie wyrażanie własnej opinii, wskazuje na wzrost znaczenia otwartej debaty w społeczeństwie Tajwanu. Jak wskazują cytowani badacze, „obecnie praktyki dyskursywne redefiniują styl i charakter tajwańskich dyskusji socjopolitycznych na Tajwanie. Obsesja otwartego mówienia (kaijiang) stopniowo zastępuje partyjne kongresy »za zamkniętymi drzwiami« jako sposób podejmowania decyzji politycznych"’31. Wydaje się, że właśnie tymi przemianami tłumaczyć można bardzo niski odsetek wskazań na ważność „rozwiązywania sporów politycznych na drodze prywatnych ustaleń" - wartość ta uzyskała bowiem jedynie 13,7\% wskazań. Zaskakujący wobec powyższej refleksji nad mediami, choć mniej zadziwiający w kontekście... lingwistycznym jest niski odsetek wskazań na „samodzielne myślenie”. Zostało ono wskazane jako istotne w społeczeństwie tylko przez 23,5\% badanych. Wydaje się, że samo wyrażenie języka chińskiego wei ziji zhe xiang (為自己著想), będące odpowiednikiem angielskiego thinking for oneself znacznie mocniej implikuje nie tylko sposób, ale i cel takiego myślenia - określając pośrednio ,ja” jako beneficjenta. Tak rozumiane „samodzielne myślenie" wydaje się być aspołeczne nie dlatego, że dokonywane samodzielnie, ale jako „egoistyczne" i niedostatecznie biorące pod uwagę cele innych, jak i warunki społeczne. Nie mająca wspomnianego w przypadku ,samodzielnego myślenia" negatywnego obciążenia semantycznego „wolność wypowiedzi” okazuje się mieć nadrzędną wręcz wartość społeczną - bowiem aż 60,5\% badanych wskaza-

\footnotetext{
${ }^{31}$ Ibidem.
} 
ło na nią, jako na szczególnie ważną w ich społeczeństwie. Wynik ten sytuuje tę wartość jako bezsprzecznie najważniejszą pośród wartości społecznych.

Wydaje się, że postrzeganie nadrzędnej ważności wolności wypowiedzi na Tajwanie zyskuje swój odpowiednik w strukturze sceny publicznej, obejmującej nie tylko scenę profesjonalnej polityki, ale także - często dosłownie - scenę dla wypowiedzi poszczególnych grup społecznych, ugrupowań, bądź stowarzyszeń, które, po zniesieniu stanu wyjątkowego w roku 1987 zaczęły swój dynamiczny rozwój. Rozwój ten wykorzystywał, jak argumentują niektórzy badacze, tradycyjne możliwości i istniejące powiązania społeczne chińskiego społeczeństwa do wytwarzania struktur adekwatnych dla społeczeństwa obywatelskiego. Grupy takie - działające często w sferach pozapolitycznych - potrzebowały zyskać prawo wypowiedzi do sprawnego realizowania swych celów. Interesującym przykładem wykorzystania wolności słowa jest istnienie w rzeczywistości społecznej nowoczesnych organizacji religijnych buddyzmu Chan - takich jak chociażby Fo Jiao Ci Ji Ji Jin Hui(佛教 慈濟基金會). Ta potężna buddyjska organizacja charytatywna wykorzystała wolność słowa do mobilizacji na rzecz pomocy - wolność słowa stała się warunkiem skuteczności szeroko zakrojonych działań charytatywnych - mogących być rozumianymi jako element kształtującego się społeczeństwa obywatelskiego.

Także poszczególne jednostki, nie zaś ugrupowania, wraz z przemianami systemu politycznego były zachęcane do dosłownego „zabierania głosu”32. Warto wspomnieć, że koncepcja ta, określana też jako nastawienie „reprezentuję samego siebie", po przybraniu dosłownej formy zyskała trwałe miejsce w krajobrazie np. stolicy wyspy. W Tajpej nie brakuje miejsc, gdzie „wolność wypowiedzi” praktykowana jest w sposób literalny - specjalna scena wyposażona w system nagłaśniający oraz audytorium stwarza okazję zwykłym przechodniom w pobliżu pałacu prezydenckiego do ćwiczenia wypowiadania własnego zdania politycznego czy też formułowania opinii dotyczącej życia własnej społeczności. Kreuje też możliwość interakcji - co sprawia, że wartość ta nabiera konkretnego kształtu społecznego, nie tak, jak mające abstrakcyjny charakter „,prawa jednostki” - które zyskaty $34 \%$ wskazań.

\section{Zamiast konkluzji - Tajwan i Wietnam - paradoksy modernizacji?}

Do tej pory wspomniane już badanie wietnamskie było przywoływane jedynie sporadycznie, jako tło dla prób wyjaśnienia zagadnień sugerowanych przez wyniki badania tajwańskiego. Jednakże wydaje się, że kusząca jest sama próba porównania wyników obydwu badań (tabele 6 i 7).

${ }^{32}$ Chen Yueh-ying, Social change and collective memory: Taiwan's two pasts, [dysertacja doktorska], Athens Georgia 1998, s. 135. 
Tabela 6.

Porównanie badań przeprowadzonych w Wietnamie przez Instytut Socjologii UW oraz badań zrealizowanych na Tajwanie, wartości społeczne



Tabela 7.

Porównanie badań przeprowadzonych w Wietnamie przez Instytut Socjologii UW oraz badań zrealizowanych na Tajwanie, wartości osobiste

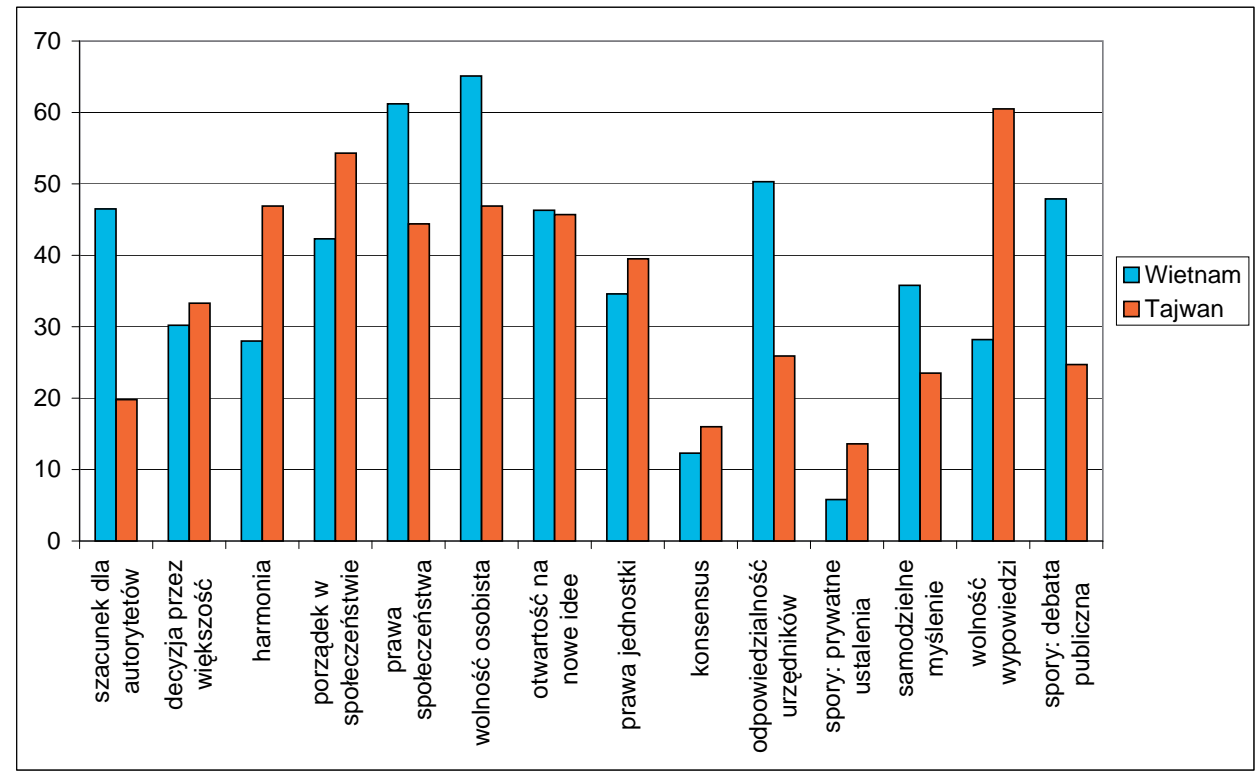


Społeczeństwo tajwańskie, choć wydające się niepomiernie dalej niż wietnamskie zaangażowane $\mathrm{w}$ procesy modernizacji $-\mathrm{w}$ aspekcie wartości społecznych okazuje się przeważnie wyżej niż wchodzące dopiero w okres przyśpieszonego rozwoju ekonomicznego społeczeństwo wietnamskie cenić wartości określane jako tradycyjne dla kręgu kulturowego, do którego oba należą - takie jak ,harmonia w społeczeństwie” czy panujący w nim „,porządek”. Mniej zaś cenione są uchodzące za znaki modernizacji wartości takie jak ,samodzielne myślenie” bądź „wolność osobista”. Wyniki porównania okazują się być paradoksalne nie tylko zresztą z punktu widzenia teorii modernizacji, ale także z punktu widzenia tzw. teorii „westernizacji”. Historia ostatnich kilkudziesięciu lat obydwu krajów sytuuje je bowiem na przeciwległych pozycjach względem implementacji wzorów, zachowań, produktów bądź wartości niesionych przez tzw. Zachód - upostaciowany zwłaszcza w Stanach Zjednoczonych Ameryki. Warto zarazem zaznaczyć, że badanie wietnamskie było prowadzone na uczelniach Hanoi, co w szczególny sposób faworyzowało wybór jako badanych osoby pochodzące z regionów, gdzie wartości przekazywane przez komunistyczne, antyzachodnio i antyamerykańsko nastawione państwo miały dłuższą tradycję i oddziaływanie ${ }^{33}$. Z kolei szczególna sytuacja międzynarodowa Tajwanu - mające swe korzenie nie tylko w aliansach Republiki Chińskiej z czasów, gdy umiejscowiona była na kontynencie, ale i jej historii na wyspie, a także otwartości Tajwanu na produkty amerykańskiej kultury popularnej, zdawała się, w świetle teorii okcydentalizacji, szczególnie predestynować badanych do przyjmowania systemu wartości bliższego systemowi ,amerykańskiemu". Tak jednak się nie stało.

Ten szczególny paradoks widoczny nie tylko z perspektywy teorii modernizacji, ale i tzw. „westernizacji” ukazuje, jak się wydaje, konieczność zrewidowania samych pojęć takich jak tradycja - w tym przypadku „tradycja konfucjańska”, czy „nowoczesność”, a także konieczność ponownej refleksji nad relacją obecności produktów i idei pochodzenia zachodniego a ich wpływem na wyobrażenia społeczne. Konieczne wydaje się także zrewidowanie roli ośrodka władzy - jako ośrodka wytwarzania kultury oficjalnej i co za tym idzie, także i rekonstruowania tradycji. Tradycja - po części odnaleziona, a po części zrekonstruowana w postaci tajwańskiego neokonfucjanizmu, wprzęgnięta w ramy nowoczesnego państwa i jego legitymizacji okazała się czymś znacznie więcej niż „stanem przeszłym”, bądź też historycznie uwarunkowanym czynnikiem kształtującym bieg nowoczesności w perspektywie ,ścieżki zależności”. Sama zaś implementacja produktów czy to kultury popularnej, czy kultury wyższej pochodzenia zachodniego nie powodowała ich automatycznego oddziaływania na sferę przekonań. Wręcz przeciw-

${ }^{33} 64,6 \%$ respondentów badania prowadzonego w Wietnamie deklarowało pochodzenie stołeczne. 
nie - jak ukazują przykłady przytoczone we wstępie niniejszego opracowania mogły przyczyniać się one do utrwalenia wzorów lokalnych. Różnice w kształcie systemu wartości wyznawanych przez młodych Tajwańczyków i przez młodzież wietnamską ukazuje pośrednio, że dyskurs oparty na różnicach pomiędzy Wschodem a Zachodem, skupiający się na analizie możliwych kształtów „zderzeń cywilizacji" nie tylko po części obraz cywilizacji tych wytworzył, ale też, być może, przyczynił się do marginalizowania problemu znacznych różnic w sferze wyznawanych wartości pomiędzy państwami regionu.

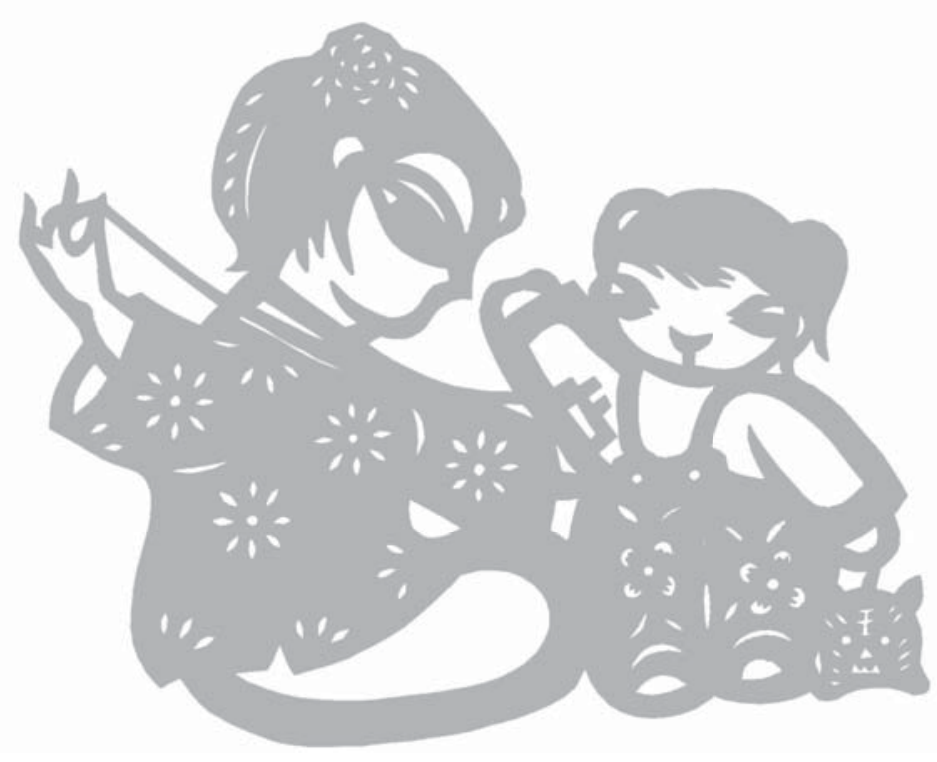

